УДК 574.63:621.311.25

Doi: https://doi.org/10.32918/nrs.2019.2(82).10

\section{Проблема біологічних} перешкод в роботі AEC (на прикладі експлуатації

\section{техноекосистеми Запорізької AEC)}

Федоненко О. В.

Дніпровський національний університет ім. О. Гончара, м. Дніпро, Україна

ORCID:https://orcid.org/0000-0001-9702-6589

Маренков О. М.

Дніпровський національний університет ім. О. Гончара, м. Дніпро, Україна

ORCID:https://orcid.org/0000-0002-3456-2496

Петровський О. О.

Дніпровський національний університет ім. О. Гончара, м. Дніпро, Україна

В статті наведено результати досліджень біологічних перешкод водойми-охолоджувача Запорізької AEC, які можуть порушувати технологічні цикли станції або навіть викликати аварійніабо надзвичайні ситуації в роботі AEC. Ця проблема має особливе значення для водоймохолоджувачів енергетичних об'єктів, оскільки підвищений температурний режим у таких водоймах створює сприятливі умови для масового розвитку окремих видів гідробіонтів, які перешкоджають роботі гідротехнічних споруд.

Встановлено, що для досліджуваної водойми-охолоджувача Запорізької AEC характерні всі види біологічних перешкод, які зустрічаються в технічних водоймах атомних електростанцій України. Найбільш поширеними $\epsilon$ біоперешкоди бактеріального, рослинного і тваринного походження. Рослинні біоперешкоди представлені надмірним розвитком планктонних синьо-зелених водоростей, які в літній період зумовлюють «цвітіння» водойми-охолоджувача, та нитчастими водоростями, які формують зарості на поверхнях бетонних плит і гідротехнічних споруд. До біоперешкод зоогенного характеру відноситься значне поширення молюсків родини Thiaridae які були випадково вселені до водойми і утворили масові обростання гідротехнічних споруд АEC.

Одним із напрямів біологічної боротьби із біоперешкодами y водоймі-охолоджувачі Запорізької AEC $\epsilon$ іхтіомеліорація біомеліоративне зариблення. Оскільки риби займають вищі трофічні рівні в водних екосистемах, вони акумулюють органічні речовини інших трофічних ланок і здатні стримувати масовий розвиток гідробіонтів.

Представлені наукові результати лягли в основу «Технологічного обгрунтування застосування біологічного методу зниження кількості фітопланктону та молюсків у гідротехнічній системі ЗАЕС та прове дення біомеліоративних робіт з використанням риб-біомеліораторів на період 2018-2022 рр.», дотримання якого дозволяє частково вирішити проблеми біологічних перешкод, викликаних масовим розвитком окремих видів.

Ключові слова: біологічні перешкоди, техноекосистема AEC водойма-охолоджувач, гідроекосистема, молюски, водорості.

(C) Федоненко О. В., Маренков О. М., Петровський О. О., 2019
B одойми-охолоджувачі атомних електростанцій це відкриті технологічні екосистеми, які мають джерела водопостачання та точки водовідведення, а самі водойми відкриті для біологічних об'єктів. У зв'язку з цим у водоймі-охолоджувачі можуть як постійно мешкати, так і потрапляти різні види гідробіонтів (водорості, макрофіти, молюски, риби, ракоподібні та інші), які можуть створювати біоперешкоди в роботі гідротехнічних споруд АЕС [1]. Вселення гідробіонтів може проводитися як спеціально з метою біологічної меліорації, так і випадково шляхом саморозселення видів або за участі людини [2].

На сьогоднішній день питання біообростання підводних об'єктів атомної енергетики залишається актуальним [3]. Експлуатація технічних водоводів нерідко ускладнюється внаслідок заселення поверхонь, що омиваються водою, різного роду рослинними і тваринними організмами $[1,3]$. Обростання гідротехнічних споруд утворює проблеми для їх функціонування [4]. Обростання водозабірних споруд і водоводів зменшує їх ефективність, і може привести до практичного закупорювання водоводу [5].

Значна частина гідробіонтів у водоймі-охолоджувачі в тій чи іншій мірі впливає на формування біологічних перешкод у роботі гідротехнічних систем АЕС, що може негативно вплинути на технологічні характеристики технічних споруд і створювати аварійні або надзвичайні ситуації. $\mathrm{E}$ повідомлення, що протягом 2000-2008 pp. у різних країнах світу відбулося до 40 аварійних зупинок ядерних енергоблоків унаслідок перекриття постачання охолоджувальної води, абсолютна більшість причин мала біогенну природу [6].

Для водойм-охолоджувачів енергетичних об'єктів ця проблема має особливе значення, оскільки підвищений температурний режим у таких водоймах створює сприятливі умови для бурхливого розвитку окремих видів гідробіонтів, про що неодноразово вказувалося в науковій та спеціальній літературі [7-11].

\section{Аналіз літературних даних}

Біоперешкоди можуть викликати як аборигенні види, так і вселенці. Вселення нових видів гідробіонтів може відбуватися як 3 найближчих водойм, так і 3 водойм досить віддалених регіонів [1]. Наприклад, поява у водоймі-охолоджувачі Запорізької АЕС сонячного окуня та чебачка амурського - $є$ наслідком біологічної інвазії риб шляхом випадкового проникнення даних видів до водойми [2]. Оскільки на сьогодні по каскаду водосховищ Дніпра відбувається саморозселення морських видів риб, а також поширення нових видів шляхом випуску екзотичних видів (гупі, піранії, плекостомуси тощо). Не виключено попадання до водоймиохолоджувача декількох видів бичків, причиною поширення яких є загальне підвищення температури в умовах глобальних кліматичних змін і постійної підвищеної температури водойми-охолоджувача Запорізької АЕС [1, 2]. Певна термофільність гідробіонтів може бути передумовою масового розвитку їх популяцій в штучних водоймах-охолоджувачах. У той же час, як зазначено С. П. Озінковською та співавторами [12], високі температури води $\left(+29{ }^{\circ} \mathrm{C}\right.$ і вище) негативно впливають на популяції аборигенних видів риб, пригнічуючи їх розмноження, що також може бути передумовою значних змін в складі гідробіоценозів водойми-охолоджувача $[1,12]$. Пригнічення популяцій аборигенних видів риб водойми-охолоджувача (ВО) ЗАЕС можна прослідкувати на прикладі плітки та краснопірки, які не витримали значних підвищень температури води в літній період і випали зі списку фауни водойми [2]. 
Окрім риб, до водойми можуть потрапити і безхребетні (молюски, ракоподібні, кишковопорожнинні, губки та ін.), так наприклад, до водойми-охолоджувача ЗАЕС потрапили два види молюсків роду Thiaridae [13]. Після їх вселення до водойми-охолоджувача, в технічних системах водопостачання виникли істотні проблеми, пов'язані з обростанням на різних ділянках. 32013 року в водойміохолоджувачі Запорізької АЕС відзначена поява молюсків родини Thiaridae: Melanoides tuberculata (Mьller 1774) i Tarebia granifera (Lamarck, 1822), які натуралізувалися, збільшили свою чисельність і поширилися по всій водоймі. В якості технічної передумови виникнення біологічних перешкод у водоймі-охолоджувачі ЗАЕС можна розглядати наявність досить протяжного підвідного каналу, в якому в першу чергу і в значній кількості на бетонних схилах сформувалися поселення молюсків M. tuberculata i T. granifera.

Життєдіяльність гідробіонтів у джерелах водопостачання та у водоймах-охолоджувачах АЕC в тій чи іншій мірі впливають на якість води водойми-охолоджувача і на формування біологічних перешкод у роботі гідротехнічних споруд атомних станцій $[1,14]$.

До видів, які представляють потенційну загрозу створюючи біоперешкоди в роботі АЕС помірної кліматичної зони, крім поширених молюсків роду Dreissena відносяться також губки Spongilla lacustris L., Ephydatia mulleri Liberkiihn, мшанки Plumatella emarginata Alm. і P. fungosa Pallas, медуза Craspedacusta sowerbii Lankester, 1880, поліп Cordilophora caspia Pallas, а також нитчасті водорості (Cladophora, Ulotrix), вищі водні рослини (очерет звичайний Phragmites australis (Cav.) Trin. ex Steud [1, 14]. У водоймі-охолоджувачі ЗАЕС до таких організмам в першу чергу слід віднести молюсків роду Thiaridae [13].

За класифікацією дослідників [1] можна виділити 6 основних груп біоперешкод водойм-охолоджувачів ЗАЕС. Перешкоди, які виникають (за Протасовим О.О.) [1, 10]:

І група - біоперешкоди у водоймі-охолоджувачі, що призводять до відхилень від його проектних характеристик;

II група - біоперешкоди в системах підведення та відведення циркуляційної води, що охолоджується, пристроях додаткового охолодження води (підвідний, відвідний канали, бризкальні басейни, градирні);

III група - біоперешкоди в системах циркуляційного водопостачання та теплообмінниках (конденсаторах);

IV група - біоперешкоди в системі водоводів агрегатів технічного водопостачання;
V група - біоперешкоди в системі хімічної водопідготовки;

VI група - біоперешкоди в системах водопостачання з зовнішніх джерел.

\section{Постановка завдань дослідження та мета статті}

Таким чином, визначення основних видів біоперешкод в умовах водойми-охолоджувача Запорізької АЕС направлені на загальну гідроекологічну оцінку стану водойми-накопичувача та розробки заходів щодо мінімізації негативного впливу біологічних об'єктів на роботу гідротехнічних споруд АЕС. Метою роботи було визначення як існуючих, так і потенційних біоперешкод в роботі атомних електростанцій з використанням матеріалів, зібраних при обстеженні водойми-охолоджувача Запорізької АЕС.

Завдання:

- Розподілити існуючі та потенційні біологічні перешкоди в роботі АЕС, на прикладі гідробіологічних досліджень водойми-охолоджувача ЗАЕС.

- Визначити можливі дієві напрями боротьби із біоперешкодами.

\section{Матеріали досліджень, експериментальна частина}

Дослідження проводили на акваторії водойми-охолоджувача Запорізької атомної електростанції (м. Енергодар) в рамках технічного завдання «Технологічне обгрунтування застосування біологічного методу зниження кількості фітопланктону та молюсків у гідротехнічній системі ЗАЕС та проведення біомеліоративних робіт 3 використанням риб-біомеліораторів на період 2018-2022 рр.». Дослідження виконували протягом вегетаційного періоду 2017 року. Збір та опрацювання гідробіологічних проб проводили відповідно до загальноприйнятих методик [15].

\section{Результати досліджень}

Біоперешкоди I типу пов'язані з процесами заростання водойми вищою водною рослинністю (рисунок 1). Це призводить до зменшення активної поверхні теплообміну та впливає на гідродинамічний режим. За рахунок масового розвитку рослин зменшується проточність та швидкість водообміну [1].

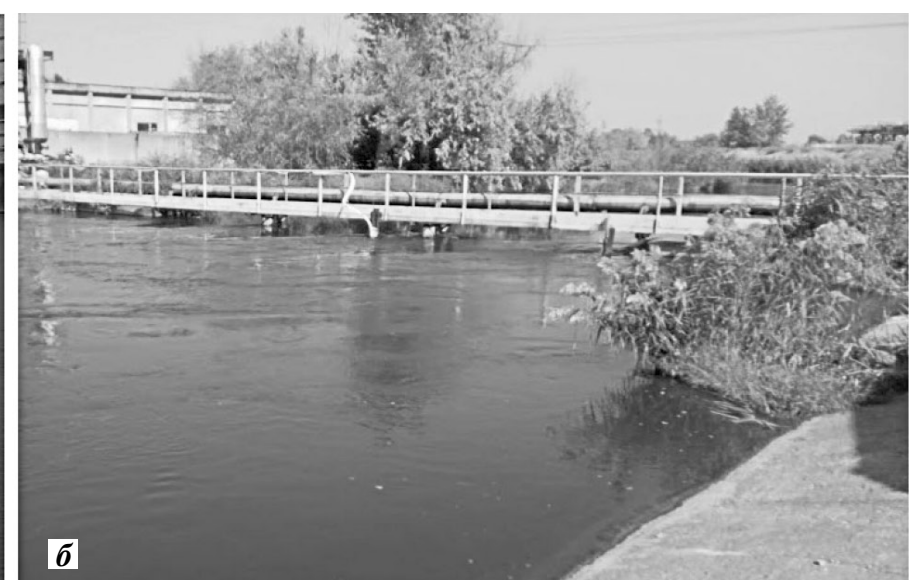

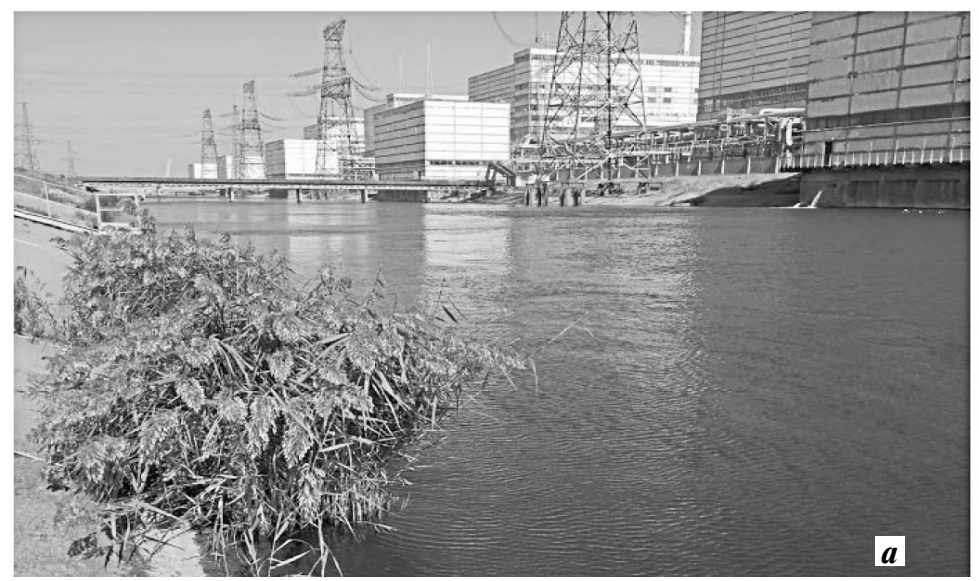

Рисунок 1 - Приклад розташування заростей очерету звичайного:

А - відвідний канал, Б - підвідний канал (фото Маренкова О. М.). 


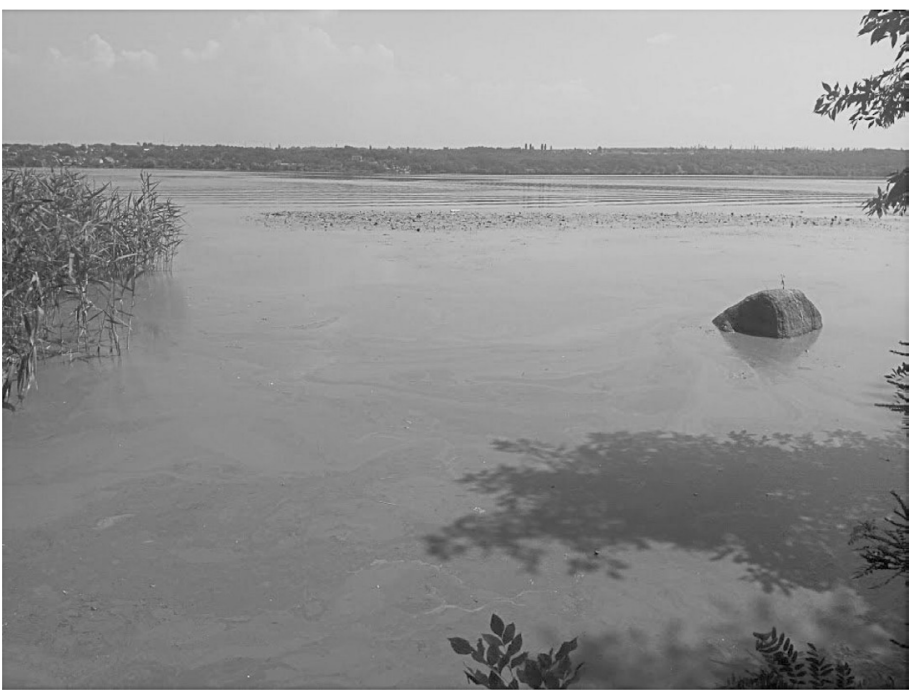

Рисунок 2 - Масовий розвиток синьо-зелених водоростей роду Microcystis, «цвітіння» водоростей у водоймі-охолоджувачі (фото Маренкова О. М.).

Рослини у водоймі-охолоджувачі ЗАЕС розвиваються майже протягом всього року. Для їх росту та розвитку необхідне сонячне світло, тому в водоймі-охолоджувачі ЗАЕС вони ростуть та нарощують свою чисельність та біомасу всюди, крім затемнених ділянок систем водовідведення та водопостачання. Їстотну роль в розподілі різних рослин відіграє температурний режим водойми. Наприклад, масовий розвиток нитчастих і синьо-зелених водоростей відбувається в зонах скидання підігрітих вод.

Біологічні перешкоди і зміну якості водного середовища викликають скупчення на поверхні води мікроскопічних планктонних водоростей, які зумовлюють масове «цвітіння» води (синьо-зелені водорості Cyanobacteria, зелені водорості Chlorophyta (рисунок 2), спливаючих нитчастих водоростей (Hydrodictyon), скупчення рослин із плаваючим листям (ряска роду Lemna, пістія роду Pistia, сальвінія Salvinia natans), що призводить до зниження тепловіддачі води, зменшуючи площу відкритого водного дзеркала та акумулюючи тепло від сонячних променів. Також масовий розвиток водних рослин зменшує прозорість води, що також посилює ефект поглинання сонячних променів.

До біологічних перешкод I типу також відносяться скупчення на дні водойми масивних донних відкладень. Мулонакопичення зазвичай має біологічне походження і представляє собою сукупність органічного детриту, раковин відмерлих молюсків, залишків рослин і водоростей [1]. Накопичення мулових відкладень призводить до зменшення глибини водойми, створюючи значні поклади біогенних елементів, які можуть сприяти масовому розвитку мікроскопічних водоростей - «цвітінню» води. Також потоком води донні відкладення вимиваються і надходять до системи водопостачання у вигляді біогенних наносів.

І̇ноді біоперешкодою може бути масовий розвиток дрібних організмів зоопланктону (деяких ракоподібних представників Daphnia, Cyclopidae), що призводить до їх потрапляння до системи водопостачання та викликає погіршення фільтраційної здатності обертових сіток берегових насосних станцій АЕС [5].

Біоперешкоди II типу небезпечні в підвідних каналах, тому що вони впливають на роботу берегових насосних станцій і систем водопостачання АЕС [1]. Слід враховувати,

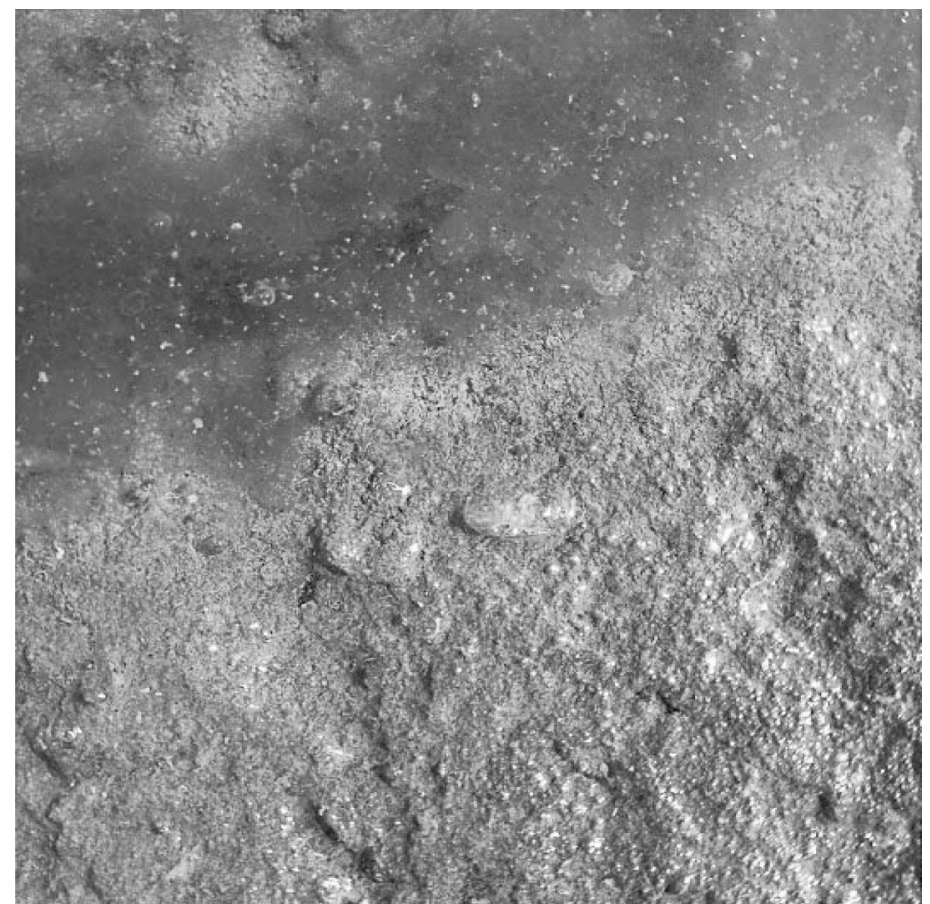

Рисунок 3 - Скупчення водоростей Cladophora на бетонних стінках каналу (фото Маренкова О. М.).

що в підвідному каналі ЗАЕС складаються оптимальні сприятливі умови для розвитку багатьох гідробіонтів, зокрема молюсків Melanoides tuberculata і Tarebia granifera у зв'язку з постійною течією, сприятливим кисневим режимом, заростями берегів каналу рослинами.

Через підвищену температуру води і значну освітленість гідротехнічних ділянок відбувається масовий розвиток нитчастих водоростей, що призводить до збільшення гідравлічної шорсткості бетонних укосів каналів (рисунок 3).

В свою чергу поселення та масовий розвиток в каналі водних організмів, що викликають біоперешкоди, можуть створювати умови для поселення інших гідробіонтів [1]. Наприклад, в умовах ЗАЕС розростання очерету звичайного на урізі бетонних плит каналів створює умови для масового розвитку та концентрації черевоногих молюсків Melanoides tuberculata і Tarebia granifera, які утворюють скупчення в коріннях очерету (рисунок 4).
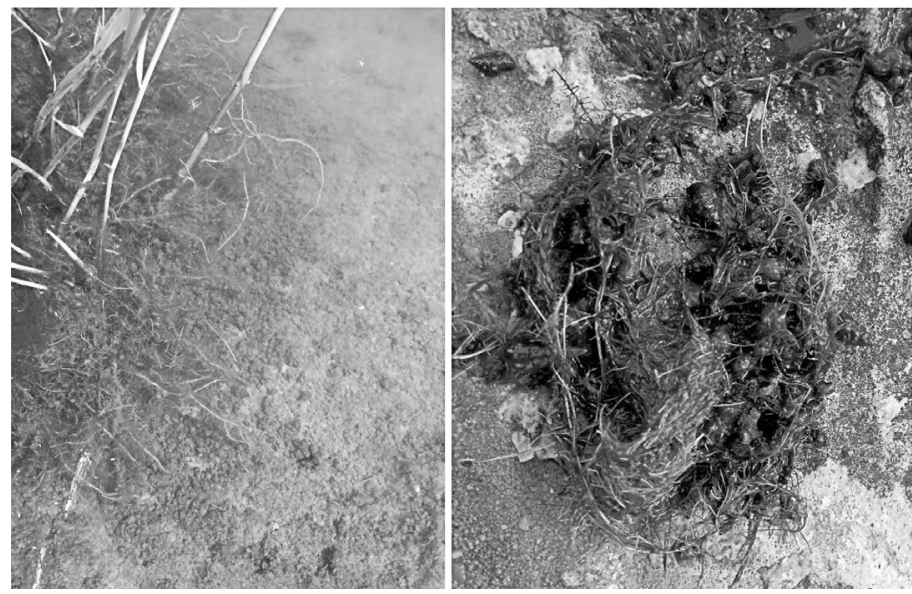

Рисунок 4 - Скупчення молюсків Melanoides tuberculata і Tarebia granifera в заростях очерету (фото Маренкова О. М.). 

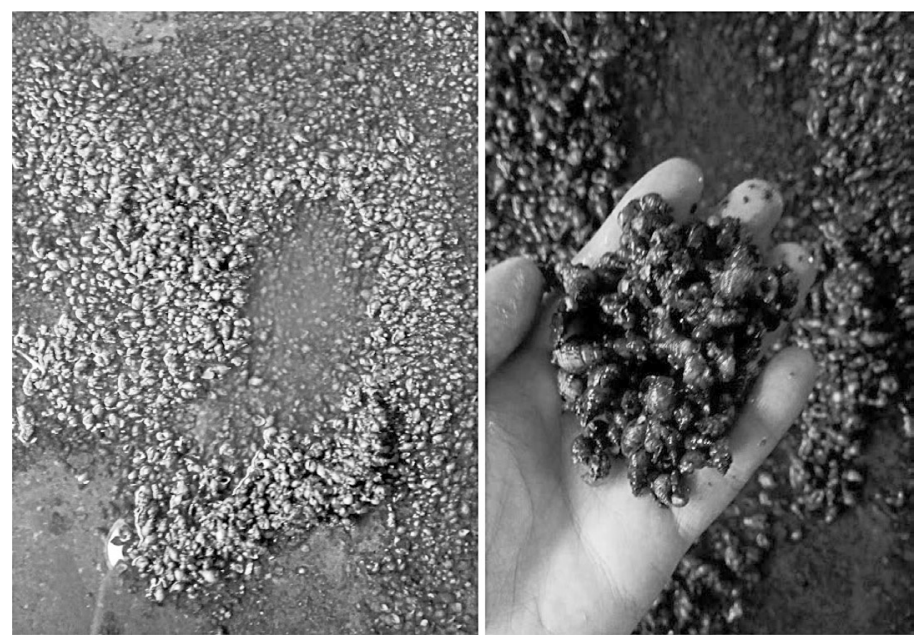

Рисунок 5 - Винос раковин мертвих молюсків на берегових насосних станціях (фото Маренкова О. М.).

Біоперешкоди III типу можуть бути як наслідком попадання біогенного матеріалу (раковини молюсків, нитчасті водорості, вищі водні рослини, дрібні риби) в систему водопостачання, так і розвитку обростання в самій системі [1]. В останньому випадку найбільшу небезпеку становлять поселення молюсків Dreissena bugensis, Dr. polymorpha, Melanoides tuberculata і Tarebia granifera, губок, мшанок, поліпів прісноводних медуз роду Craspedacusta.

Біоперешкоди IV типу виникають в водоводах систем технічного водопостачання. Вони характеризуються принесенням живих організмів і біогенного матеріалу ззовні або інших ділянок систем і розвитком організмів безпосередньо в системах водопостачання [1].

Відмирання організмів, пов'язане з підвищенням температури і швидкості течії в підвідному каналі, позначається на кількості дрифтового матеріалу, що викликає біоперешкоди в роботі берегових насосних станцій. Загиблі раковини молюсків також течією води переносяться до берегових насосних станцій та накопичуються у басейнах ділянки біомеліорації ЗАЕС (рисунок 5).

Біоперешкоди $\mathbf{V}$ типу мають бактеріальне походження та пов'язані з розвитком бактеріальних плівок на поверхні

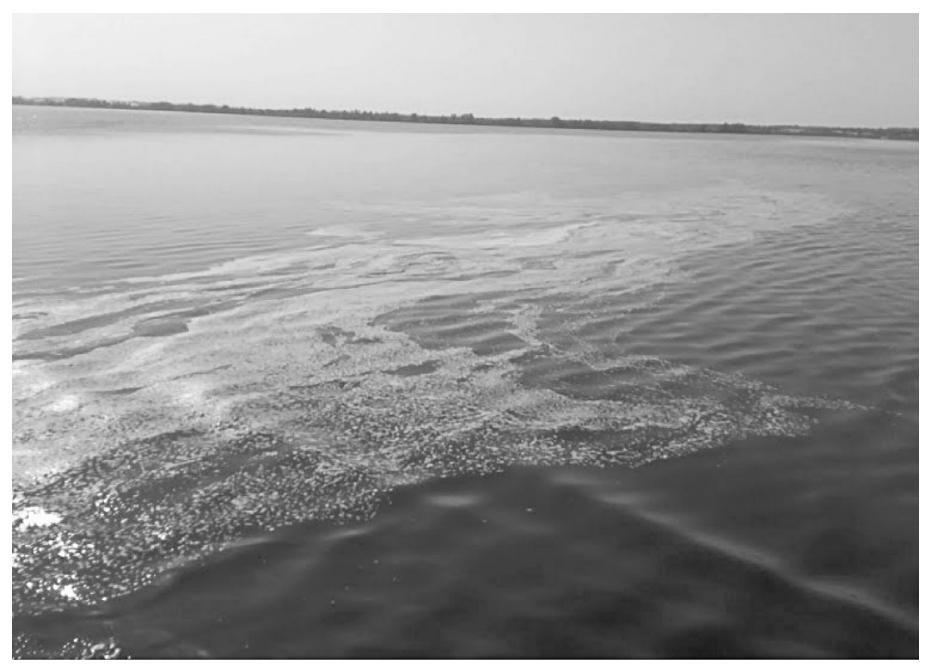

Рисунок 6 - Бактеріальна біоплівка на поверхні ВО ЗАЕС, вересень 2017 р. (фото Маренкова О. М.). водойм і гідротехнічних споруд. В літній період за рахунок підвищення температури води водойми-охолоджувача (ділянки поблизу градирень можуть мати температуру $\left.+40{ }^{\circ} \mathrm{C}\right)$ прискорюються процеси життєдіяльності водних організмів i, за наявності великої кількості органічної речовини, на поверхні водойм можуть створюватися значні площі біоплівок бактеріального походження, які негативно впливають на якість води (рисунок 6).

Утворення бактеріальних біоплівок на поверхні водойм і на теплообмінних поверхнях провокує зниження концентрації кисню у воді і може викликати загибель гідробіонтів. В свою чергу масова загибель гідробіонтів у водоймі-охолоджувачі при значному підвищенні температури води може призвести до збільшення концентрації органічної речовини у водойми і стимулювати подальший розвиток бактерій.

Біоперешкоди VI типу виникають в каналах підживлення, вони порушують систему водопостачання водоймиохолоджувача АЕC [1]. В каналах підживлення водоймиохолоджувача ЗАЕС зустрічаються поселення Dr. bugensis, Dr. Polymorpha, які за певних умов можуть нарощувати свою чисельність.

\section{Інтерпретація результатів та їх апробація}

Таким чином, для водойми-охолоджувача ЗАЕС характерна наявність всіх 6 видів біоперешкод. Критичними є: масовий розвиток синьо-зелених водоростей, заростання берегів та каналів з вищою водною рослинністю, розвиток нитчастих водоростей, замулення та неконтрольований розвиток молюсків родини Thiaridae.

В умовах водойми-охолоджувача ЗАЕС біоперешкоди тваринного походження утворюють молюски, переважно це молюски-вселенці Melanoides tuberculata i Tarebia granifera. Як види-вселенці вони швидко займають різні біотопи. Останні три роки вони різко збільшують чисельність, що характерно для нових видів на початкових стадіях вселення. Гідробіологічні дослідження водойм ЗАЕС показали, що максимальне скупчення молюсків спостерігається в прибережній зоні на каменях (рисунок 7), у поверхні бетонних плит, в щілинах між бетонними плитами каналів, в тіні заростей вищої водної рослинності, в коренях очерету звичайного Phragmites australia і поблизу угрупувань водоростей роду Cladophora.

Чисельні популяції молюсків сформували постійні поселення на бетонних схилах підвідного каналу ЗАЕС (рисунок 8). Саме вони є потужним джерелом молоді молюсків та раковин відмерлих молюсків, які потрапляють в технічні системи водопостачання атомної станції.

Підвищення температури води у скидному каналі та у водоймі-охолоджувачі може привести до більш інтенсивного розвитку молюсків, які будуть розвиватися як у зворотному і підводному каналах, так і в системах охолодження і технічного водопостачання.

За відсутності в іхтіофауні видів, які споживають гідробіонтів, що створюють біоперешкоди, виникає велика ймовірність збільшення у водоймі-охолоджувачі їх популяцій, розвиток яких, може протікати спонтанно та бурхливо. Наприклад, за наявності задовільних умов може спостерігатися сплеск чисельності молюсків роду Dreissena (рисунок 9), що значно загострить проблему біологічних перешкод: масовий розвиток в підвідному каналі, обростання решіток, сіток, фільтрів, забивання трубопроводів техводопостачання. 


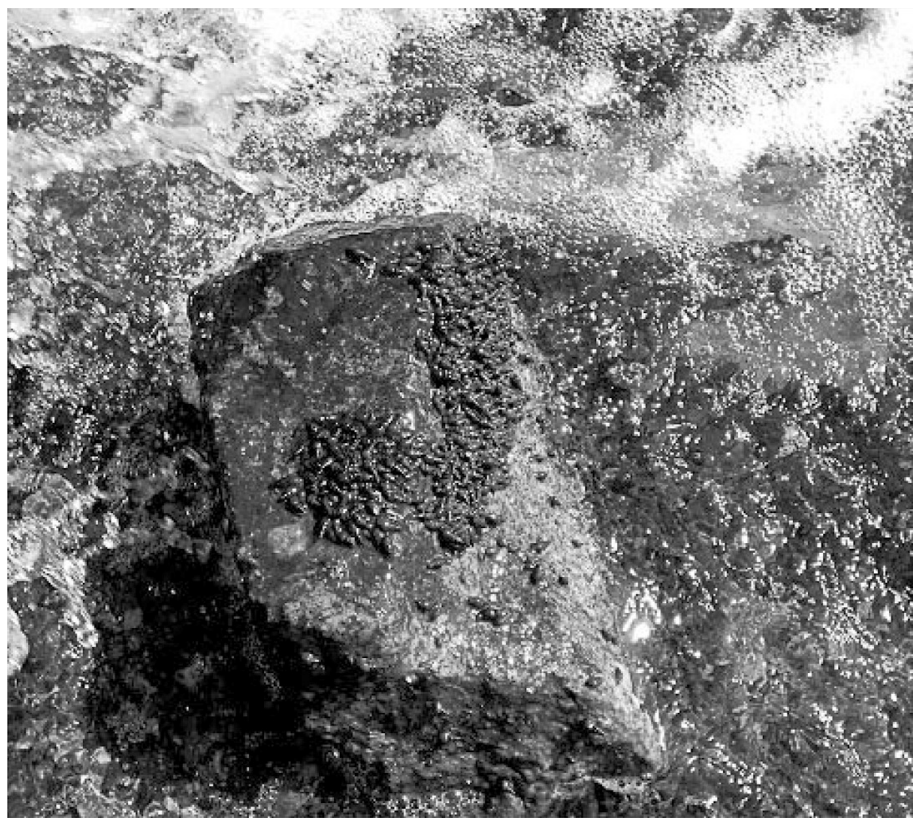

Рисунок 7 - Скупчення M. tuberculata на кам'янистому субстраті в районі скидного каналу ЗАЕС; вересень, 2017 р (фото Маренкова О. М.).

Зазначені біологічні перешкоди можна ліквідувати за рахунок направленого формування біоценозу водоймиохолоджувача ЗАЕС $з$ метою створення стабільної саморегулюючої екосистеми.

Одним із напрямів боротьби з біоперешкодами у водоймі-охолоджувачі ЗАЕС $є$ біомеліоративне зариблення рибами, які займають вищі трофічні рівні в водних екосистемах -білим товстолобиком для боротьби з масовим розвитком фітопланктону («цвітінням») та зменшенням завислих органічних речовин у воді, чорним амуром для боротьби з молюсками, білим амуром - для боротьби із заростанням водойми, тіляпією - для боротьби із біологічним обростанням плит відвідних та підвідних каналів (зменшення кількості прикріплених зелених водоростей родів Cladophora та Ulotrix), коропа - 3 метою акумуляції

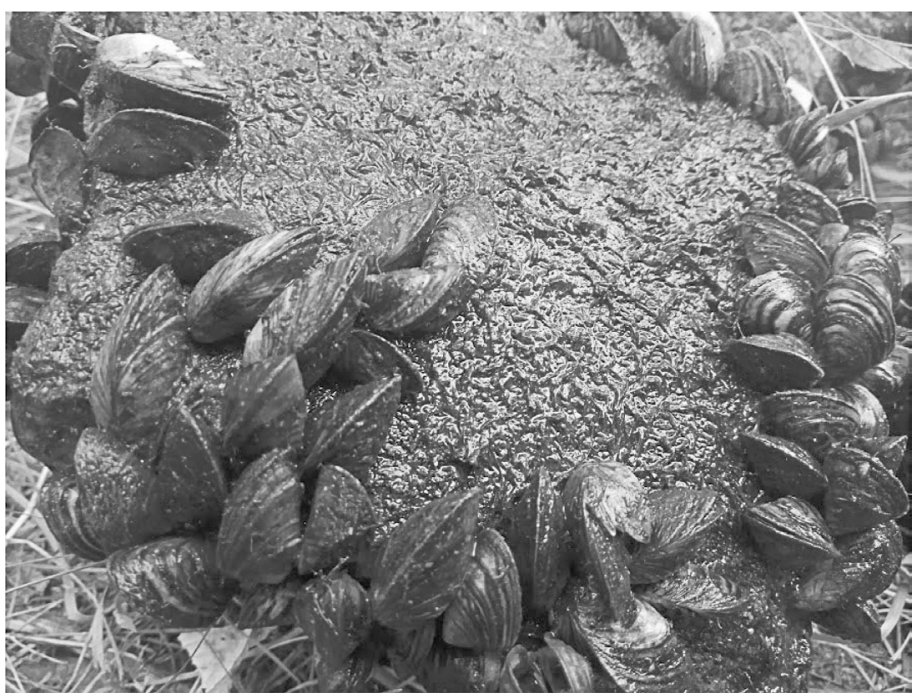

Рисунок 9 - Приклад біологічного обростання молюсками роду Dreissena (фото Маренкова О. М.).

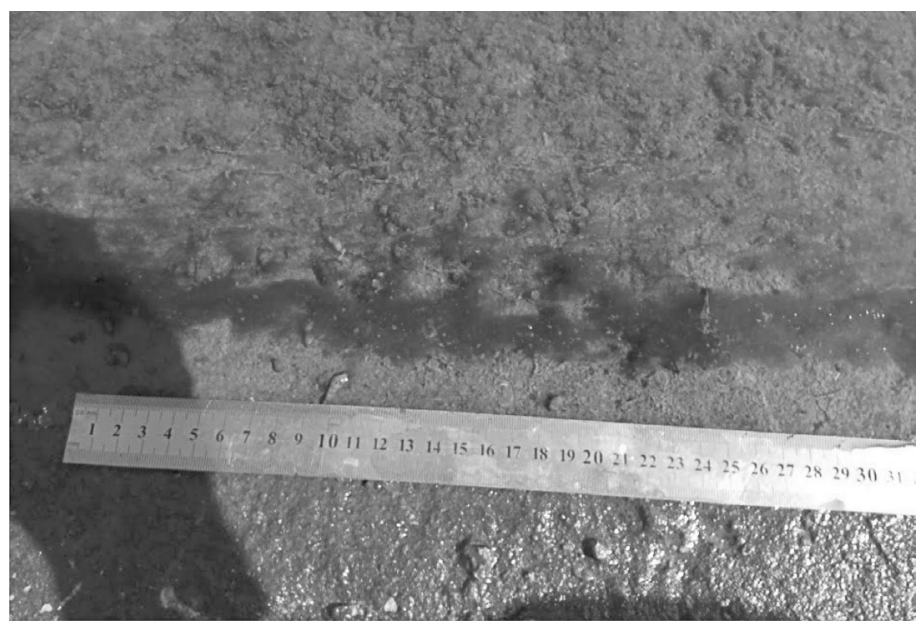

Рисунок 8 - Молюски Melanoides tuberculata і Tarebia granifera на бетонному схилі каналу ЗАЕС (фото Маренкова О. М.).

органічної речовини, яка створюється біомасою бентосних організмів, зариблення хижаками - канальним сомом з метою іхтіомеліорації. Використання риб-біомеліораторів 3 метою меліорації технічних водойм - широко поширене в Україні та світі. Суттєвого меліоративного ефекту можна досягнути лише за умов регулярного зариблення в достатніх об'ємах і постійного вилову риби з метою вилучення біогенних елементів з техноекосистеми.

Для вирішення проблем значних біологічних перешкод, викликаних появою нових видів гідробіонтів для персоналу ЗАЕС необхідно розробити нормативні документи, які б регламентували експлуатацію енергоблоків Запорізької AEC в умовах наявності перешкод біологічного походження. Подібний документ має на меті визначати стратегію та загальні принципи проведення заходів щодо безпечної експлуатації водойми-охолоджувача та систем водопостачання ЗАЕС, а також регулювати поведінку персоналу станції стосовно навмисного або випадкового вселення нових видів гідробіонтів.

Результати робіт були апробовані та впровадженні в практику роботи ЗАЕС у вигляді розробленого «Технологічного обгрунтування застосування біологічного методу зниження кількості фітопланктону та молюсків у гідротехнічній системі ЗАЕС та проведення біомеліоративних робіт з використанням риб-біомеоліораторів на період 2018-2022 pр.».

\section{Висновки}

Водойма-охолоджувач Запорізької АЕС - відкрита техноекосистема, видовий склад якої не стабільний і залежить від багатьох чинників. Подібна нестабільність екосистеми технічної водойми створює умови для масового розвитку окремих видів гідробіонтів, які через різке збільшення чисельності та біомаси змінюють технічні характеристики водойми-охолоджувача та стають біологічною перешкодою в роботі АЕC.

Для водойми-охолоджувача ЗАЕС притаманні всі види біологічних перешкод: мулонакопичення, розвиток біоплівок, біологічне обростання поверхонь гідротехнічних сполук рослинними і тваринними організмами, масовий розвиток мікроскопічних водоростей («цвітіння» води), заростання прибережних ділянок водойми. Серед основних біоперешкод варто виділити: надмірний розвиток 
бактеріальних біоплівок, «цвітіння» води синьо-зеленими водоростями в літній період, поява молюсків-вселенців Melanoides tuberculata i Tarebia granifera, які створили масові обростання гідротехнічних споруд і можуть викликати порушення в роботі системи водного охолодження ЗАЕС.

Для вирішення проблем значних біологічних перешкод, викликаних появою нових видів гідробіонтів для персоналу ЗАЕС необхідно розробити нормативні документи, які 6 регламентували експлуатацію енергоблоків Запорізької АЕС в умовах наявності перешкод біологічного походження.

\section{Список використаної літератури}

1. Протасов А. А., Семенченко В. П., Силаева А. А., Тимченко В.М., Бузевич И. Ю., Гулейкова Л. В., Дьяченко Т. Н., Морозова А.А., Юришинец В. И., Ярмошенко Л. П., Примак А. Б., Морозовская И. А., Масько А. Н., Голод А. В. Техно-экосистема АЭС. Гидробиология, абиотические факторы, экологические оценки/ под ред. А.А. Протасова. К.: Институт гидробиологии НАН Украины, 2011. 234 с.

2. Marenkov O. Ichthyofauna of the Zaporizhia Nuclear Power Plant cooling pond (Enerhodar, Ukraine) and its biomeliorative significance. Ukrainian Journal of Ecology. 2018. Vol. 8(2), P. 140-148.

3. Protasov A. A., Sylaieva A. A., Novoselova T. N., Gromova Y. F., Morozovskaya I.A., Stepanova T.I. Nuclear Power Plant technoecosystem: 18 years of hydrobiological observations. J. Sib. Fed. Univ. Biol. 2017. Vol. 10(4), P. 459-484.

4. Protasov A. A., Zubkova Ye. I., Silayeva A. A. Conceptual approaches to organization of hydrobiological monitoring of technoecosystems of thermal and nuclear power plants. Hydrobiological Journal. 2016. Vol. 52(2), P. 59-70.

5. Звягинцев А. Ю., Мощенко А. В. Морские техноэкосистемы энергетических станций. Владивосток: Дальнаука, 2010. 310 с.

6. Романенко В. Д., Кузьменко М. Ї., Афанасьєв С. О., Гудков Д. І̇. Гідроекологічна безпека атомної енергетики в Україні. Bicн. НАН України. 2012. Вип. 6. С. 41-51.

7. Протасов А. А., Сергеева О. А., Кошелева С. И., Поливанная, М. Ф. Гидробиология водоемов-охладителей тепловых и атомных электростанций Украины. К.: Наук. думка, 1991. 192 с.

8. Sakaguchi I. An overview of the antifouling technologies in power plant cooling water systems. Sessile Organisms. 2003. Vol. 20 (1), P. 15-19.

9. Силаева А. А., Протасов А. А., Морозовская И. А., Бабарига С. П. Особенности сообществ дрейссены в донных группировках водоема-охладителя Хмельницкой АЭС. Житомир: Публикации Житомир. Унив. 2006. Вып. 2. С. 262-265.

10. Протасов А. А., Панасенко Г. А., Бабарига С. П. Биологические помехи в эксплуатации энергетических станций, их типизация и основные гидробиологические принципы их ограничения. Гидробиологический журнал. 2008. Вып. 44 (5). С. 36-54.

11. Sylayeva A. A., Protasov A. A., Morozovskaya I. A. Interrelation between Unionids and its epibionts in cooling pond of nuclear power plant. Vestnik Zoologii. 2012. Vol. 46 (6), P. 533-538.

12. Озінковська С. П., Кулініч А. І̇., Діденко О. В. Сучасний стан іхтіофауни водойми-охолоджувача ХАЕС та оцінка можливого впливу на неї при введені в експлуатацію енергоблоку № 2 (еБ-2). Рибне господарство. 2000. Вип. 58. С. 84-89.

13. Marenkov O., Batalov K., Kriachek O. Biological and biomechanical principles of the controlling molluscs Melanoides tuberculata (Mbller 1774) and Tarebia granifera (Lamarck, 1822) in reservoirs of strategic importance. World Scientific News. 2018. Vol. 99, P. 71-83.

14. Громова Ю. Ф., Протасов А. А. Многолетняя динамика и распределение велигеров Dreissena в водоеме-охладителе Хмельницкой АЭС и их роль в структуре зоопланктона. Гидробиологический журнал. 2016. Вып. 52(5). С. 3-17.

15. Методи гідроекологічних досліджень поверхневих вод/ під ред. В.Д. Романенко. К.: ЛОГОС, 2006. 408 с.

\section{References}

1. Protasov, A., Semenchenko, V., Silaieva, A., Tymchenko, V., Buzevych, I., Guleikova, L., Diachenko, T., Morozova, A., Yurishinets, V., Yarmoshenko, L., Prymak, A., Morozovskaia, I., Masko, A., Golod, A. (2011). NPP Techno-ecosystem. Hydrobiology, abiotic factors, environmental assessment. Institute of hydrobiology of the NAS of Ukraine, $234 \mathrm{p}$.

2. Marenkov, O. (2018). Ichthyofauna of Zaporizhzhya Nuclear Power Plant cooling pond (Enerhodar, Ukraine) and its biomeliorative significance. Ukrainian Journal of Ecology. 8(2), pp. 140-148.

3. Protasov, A., Silaieva, A., Novoselova, T., Gromova, Y., Morozovskaia, I., Stepanova, T. (2017). Nuclear Power Plant technoecosystem: 18 years of hydrobiological observations. J. Sib. Fed. Univ. Biol., 10(4), pp. 459-484.

4. Protasov, A., Zubkova, Ye., Silaieva, A. (2016). Conceptual approaches to organization of hydrobiological monitoring of technoecosystems of thermal and nuclear power plants. Hydrobiological Journal, 52(2), pp. 59-70

5. Zviagintsev, A., Moshchenko, A. (2010). Sea techno-ecosystems of power plants. Vladivostok: Dalnauka, $310 \mathrm{p}$.

6. Romanenno, V., Kuzmenko, M., Afanasiiev, S., Gudkov, D. (2012). Hydroecological safety of nuclear industry in Ukraine. Journal of the NAS of Ukraine, No. 6, pp. 41-51.

7. Protasov, A., Sergeeva, O., Kosheleva, S., Polivannaia, M. (1991). Hydrobiology of cooling ponds of thermal and nuclear power plants of Ukraine. Kyiv: Naukova Dumka, 192 p.

8. Sakaguchi, I. (2003). An overview of the antifouling technologies in power plant cooling water systems. Sessile Organisms, 20(1), pp. 15-19.

9. Silaieva, A., Protasov, A., Morozovskaia, I., Babariga, S. (2006). Peculiarities of zebra mussel communities in bottom groups of Khmelnitsky NPP cooling pond. Zhytomyr: Zhytomyr Publications, No. 2, pp. 262-265.

10. Protasov, A., Panasenko, G., Babariga, S. (2008). Biological obstacles in power plant operation, their typification and main hydrobiological principles of their limitation. Hydrobiological Journal, 44(5), pp. 36-54

11. Silaieva, A., Protasov, A., Morozovskaia, I. (2012). Interrelation between Unionids and its epibionts in cooling pond of nuclear power plant. Vestnik Zoologii, 46(6), pp. 533-538.

12. Ozinkovska, S., Kulinich, A., Didenko, O. (2000). Current state of ichthyofauna in KhNPP cooling pond and assessment of possible impact on it in commissioning of Unit 2 (eB-2). Fish Industry, No. 58, pp. 84-89.

13. Marenkov, O., Batalov, K., Kriachek, O. (2018). Biological and biomechanical principles of controlling mollusks Melanoides tuberculata (Mbler 1774) and Tarebia granifera (Lamarck, 1822) in reservoirs of strategic importance. World Scientific News, No. 99, pp. 71-83.

14. Gromova, Yu., Protasov, A. (2016). Long-term dynamics and distribution of Dreissena veliger in Khmelnitsky NPP cooling pond and their role in zooplankton structure. Hydrobiological Journal, 52(5), pp. $3-17$

15. Romanenko, V. (2006). Methods of surface water hydroecological studies. Kyiv: LOGOS, 408 p.

\section{The Problem of Biological Obstacles in the Operation of Nuclear Power Plants (Illustrated by the Operation of Zaporizhzhya NPP Techno-Ecosystem)}

\section{Fedonenko O., Marenkov O., Petrovsky O.}

\section{Oles Honchar Dnipro National University, Dnipro, Ukraine}

The article shows the research results on biological obstacles of the Zaporizhzhya NPP cooling pond, which may be harmful for the technological cycles of the plant or even cause emergency in the NPP.

This problem is particular importance for cooling water reservoir of energy objects, since the increased temperature regime in such reservoirs creates favorable conditions for the mass development of certain types of hydrobionts, which hinder the operation of hydraulic structures. 
It was established that for the studied cooling water reservoir of Zaporizhzhya NPP all types of biological barriers that are found in technical reservoirs of nuclear power plants of Ukraine are characteristic

It has been established that all types of biological obstacles found in technical reservoirs of nuclear power plants of Ukraine are common for the researched reservoir.

The most common are biological obstacles of bacterial, plant and animal origin. Plant biological obstacles are represented by the excessive growth of blue-green algae, which in the summer cause the "water blooming" of the cooling pond, and the filamentous algae that form thickets on the surfaces of concrete slabs and hydraulic structures. Animal biomarkers include the rapid spread of the mollusks of the Thiaridae family, which were accidentally inhabited into the water reservoir and caused massive fouling of the water development facilities of the NPP.

One of the areas of biological control of biological barriers in a Zaporizhzhya NPP cooling water reservoir is ichthyomelioration biomeliorative release the fish into the reservoir As fish occupy higher trophic levels in aquatic ecosystems, they accumulate organic matter from other trophic units and can inhibit the massive development of hydrobionts.

The presented scientific results formed the basis of "Technological substantiation of the biological method of reducing the amount of phytoplankton and mollusks in the hydraulic engineering system of the ZNPP and conducting biomeliorative works using biomeliorative fish for the period 2018-2022", the observance of which allows partial resolution of the problems of biological barriers caused by the mass development of certain species.

Keywords: biological obstacles, techno-ecosystems, nuclear power plant, cooling pond, hydroecosystem, mollusks, algae.

\section{Проблема биологических помех в работе АЭС (на при мере эксплуатации техноэкосистемы Запорож- ской АЭС)}

\section{Федоненко Е. В., Маренков О. Н., Петровский А. А.}

Днепровский национальный университет имени Олеся Гончара, г. Днипро, Украина

В статье приведены результаты исследований биологических помех водоема-охладителя Запорожской АЭС, которые могут нарушать технологические циклы станции или вызывать аварийные или чрезвычайные ситуации в работе АЭС.
Эта проблема имеет особое значение для водоемов-охладителей энергетических объектов, поскольку повышенный температурный режим в таких водоемах создает благоприятные условия для массового развития отдельных видов гидробионтов, которые препятствуют работе гидротехнических сооружений.

Установлено, что для исследуемого водоема-охладителя Запорожской АЭС характерны все виды биологических помех, которые встречаются в технических водоемах атомных электростанций Украины.

Установлено, что для исследуемого водоема характерны все виды биологических помех, которые встречаются в технических водоемах атомных электростанций Украины. Наиболее распространенными являются биопомехи бактериального, растительного и животного происхождения. Растительные биопомехи представлены чрезмерным развитием планктонных сине-зеленых водорослей, которые в летний период вызывают «цветение» водоема-охладителя, и нитчатыми водорослями, которые формируют заросли на поверхностях бетонных плит и гидротехнических сооружений. К биопомехам зоогенного происхождения относится значительное распространение моллюсков рода Thiaridae, которые были случайно вселены в водоем и образовали массовые обрастания гидротехнических сооружений АЭС.

Одним из направлений биологической борьбы с биопомами в водоеме-охладителе Запорожской АЭС является ихтиомелиорация биомелиоративное зарыбление. Поскольку рыбы занимают высшие трофические уровни в водных экосистемах, они аккумулируют органические вещества других трофических звеньев и способны сдерживать массовое развитие гидробионтов.

Представленные научные результаты легли в основу «Технологического обоснования применения биологического метода снижения количества фитопланктона и моллюсков в гидротехнической системе ЗАЭС и проведения биомелиоративних работ с использованием рыб-биомелиораторив на период 2018-2022 гг.», соблюдение которого позволяет частично решить проблемы биологических препятствий, вызванных массовым развитием отдельных видов.

Ключевые слова: биологические помехи, техноэкосистема, АЭС, водоем-охладитель, гидроэкосистема, моллюски, водоросли.

Отримано 30.07.2018 